\title{
EVALUASI HASIL INDIVIDU \\ PROGRAM BOOTCAMP DIGITAL RUANGGURU 2018-2019 DI PKBM INTAN, BANDUNG
}

\author{
Rabia Edra Almira ${ }^{1}$, Ety Rahayu ${ }^{1}$ \\ ${ }^{1}$ Universitas Indonesia, Depok \\ *Corresponding Address: rabiaedraalmira@gmail.com
}

Naskah diterima: 1 November 2021| Disetujui: 9 November 2021 | Diterbitkan: 23 November 2021

Abstract: The low participation rate below the national average for high school (SMA) students in Bandung City in 2018-2019 has prompted the Ruangguru Foundation and PKBM INTAN to provide the Ruangguru Digital Bootcamp Package C program. This research aims to individually evaluate the outcomes of the program, which has carried out a set of activities related to academic education and soft skills. The program proposes to create independent and empowered individuals in order to reduce youth unemployment. Using a qualitative approach, this type of evaluative research describes the outcomes achieved based on the indicators specified by the program implementers. The evaluation is also based on the concept of empowerment in the realm of social welfare related to outof-school students. The research was conducted in-depth to a sample of beneficiaries who have the goal of working or pursuing higher education after completing all stages of the program. Through interviews and documentation studies, the research results show that the indicators of program success in the outcome aspect have been achieved, namely having a sense of self-confidence and increasing their intellectual capacity or soft skills.

Keywords: dropout students empowerment; individualized outcome; program evaluation

\begin{abstract}
Abstrak: Rendahnya angka partisipasi di bawah standar rata-rata nasional pada siswa Sekolah Menengah Atas (SMA) di Kota Bandung tahun 2018-2019, menggerakkan Yayasan Ruangguru dan PKBM INTAN menyediakan program Ruangguru Digital Bootcamp Paket C. Dalam penelitian ini, dibahas mengenai evaluasi secara individu dampak (outcomes) pada program tersebut yang telah melaksanakan serangkaian aktivitas terkait pengembangan pendidikan akademik dan keahlian diri. Tujuannya untuk menciptakan individu mandiri dan berdaya, guna mengurangi angka pengangguran muda. Dengan menggunakan pendekatan kualitatif, penelitian berjenis evaluatif ini menguraikan rincian outcomes yang telah dicapai berdasarkan indikator yang ditentukan dalam oleh pelaksana program. Evaluasi juga didasarkan pada konsep pemberdayaan dalam ranah kesejahteraan sosial terkait remaja putus sekolah. Penelitian dilakukan secara mendalam kepada representatif dari penerima manfaat yang memiliki tujuan bekerja atau menempuh pendidikan tinggi setelah menyelesaikan keseluruhan tahapan program. Melalui metode wawancara dan studi dokumentasi, hasil penelitian menunjukkan bahwa telah tercapainya indikator keberhasilan program pada aspek outcome, yakni memiliki rasa kepercayaan diri dan meningkatnya kapasitas akademik atau soft skills mereka.
\end{abstract}

Kata kunci: pemberdayaan remaja putus sekolah; individual outcome; evaluasi program 


\section{PENDAHULUAN}

Salah satu tantangan negara-negara di dunia saat ini yaitu menghadapi adanya kegagalan dalam memenuhi standar pendidikan yang memadai melalui kondisi putus sekolah (Balenzano et al., 2019). Hal ini dapat dipicu oleh 3 faktor utama seperti perilaku siswa, keluarga, serta kebijakan sekolah. Padahal dalam konteks kesejahteraan sosial, pendidikan sebenarnya adalah hal fundamental untuk meningkatkan derajat kesejahteraan masyarakat (Zastrow, 2017) dan dianggap juga sebagai bagian dari hak asasi manusia (Ife, 2009). Apabila keadaan putus sekolah terus berkelanjutan, maka akan menyebabkan kondisi ketidaksetaraan, baik dari segi ekonomi (menjadi pengangguran) maupun dari segi status sosial dimasyarakat. Analisis yang diungkapkan dari Universitas California, Los Angeles (UCLA), melihat bahwa kondisi putus sekolah pada dasarnya juga dapat membebani biaya sosial (social cost) kesejahteraan sosial dalam suatu negara (Catterall, 2011).

Merujuk kondisi di Indonesia, menurut Laporan Baseline SDGs tentang Anak-Anak di Indonesia, kelompok remaja dari $20 \%$ rumah tangga termiskin, berpeluang dua kali lebih rendah untuk menamatkan sekolah menengah (Kementerian Bappenas dan UNICEF, 2017). Tercatat, sebesar 258 juta anak dan remaja di seluruh dunia mengalami keadaan putus sekolah (UNESCO Institute for Statistics, 2006)). Sementara di Indonesia, terdapat 46 juta usia remaja atau hampir seperempat remaja di Indonesia yang tidak bersekolah, tidak memiliki pekerjaan, atau tidak mengikuti pelatihan (UNICEF, 2020). Ditinjau berdasarkan provinsi, terdapat beberapa daerah dengan angka partisipasi siswa khususnya pada jenjang SMA/sederajat yang berada di bawah standar nasional. Termasuk salah satunya Provinsi Jawa Barat yang berada pada posisi terendah dibandingkan dengan seluruh provinsi di Pulau Jawa (Badan Pusat Statistik, 2020) dan menempati urutan 28 dari 34 provinsi di seluruh Indonesia. Dibandingkan dengan total sembilan kota yang terdapat di Provinsi Jawa Barat, Kota Bandung menduduki peringkat tiga terbawah bersama dengan Kota Bogor dan Kota Cirebon (Badan Pusat Statistik Provinsi Jawa Barat, 2019). Adapun, rata-rata lama sekolah siswa di Kota Bandung setara dengan kelas 10 SMA/SMK. Sementara, Indonesia telah sejak lama meratifikasi Konvensi Hak-Hak Anak (Convention on The Rights of the Child) melalui Keputusan Presiden Nomor 36 Tahun 1990 Pasal 28 yang berbunyi "Tiap anak berhak mendapatkan pendidikan yang berkualitas. Pendidikan dasar perlu tersedia gratis, pendidikan menengah dapat diakses, dan anak didorong menempuh pendidikan hingga ke tingkat tertinggi yang dimungkinkan".

Bagi remaja yang pada akhirnya harus mengalami kondisi putus sekolah, dibutuhkan keterampilan dan dukungan tambahan jika ingin menjadi warga negara yang produktif, sebagai pencari nafkah dan konsumen. Menindaklanjuti kondisi tersebut, Yayasan Ruangguru sebagai penyedia layanan pendidikan jarak jauh nonprofit berkolaborasi dengan Pusat Kegiatan Belajar 
Mengajar (PKBM) Insan Cinta Kependidikan (INTAN), Kota Bandung. Guna memberikan kegiatan pemberdayaan bagi remaja putus sekolah sebagai penerima manfaat dengan meluncurkan program Ruangguru Digital Bootcamp (RGDB) Paket C sejak tahun 2018. Lembaga PKBM tersebut dipilih atas rekomendasi Kemendikbud serta Dinas Pendidikan Kota Bandung, sebagai lembaga yang telah tepercaya dan berpengalaman dalam menangani persiapan siswa Paket A, B, dan C yakni program ujian penyetaraan SD, SMP, dan SMA. Lebih lanjut, PKBM INTAN juga memiliki kurikulum tambahan yang disusun berdasarkan kebutuhan remaja putus sekolah dan memiliki metode belajar blended learning sejak tahun 2015. Melalui RGDB Paket C. Intervensi dilakukan atas kurangnya kualifikasi akademik baik di bidang sains atau sosial yang mumpuni pada remaja putus sekolah. Intervensi juga dilakukan guna mendukukung ketiadaan motivasi untuk mengenyam pendidikan tinggi atau mendapatkan pekerjaan yang lebih baik. Kurikulum pembelajaran pun didesain khusus selama 10 bulan dengan bentuk pembelajaran campuran (blended learning) antara penggabungan pembelajaran elektronik (e-learning) dari Yayasan Ruangguru yang dipadu kelas tatap muka oleh PKBM INTAN. Kurikulum blended learning dilakukan untuk menghasilkan pembelajaran yang adaptif. Bukan sekadar menerapkan dominasi pembelajaran daring dan mengurangi waktu tatap muka. Namun, ada peranan menggeser posisi pembelajar yang terisolasi (misalnya karena putus sekolah) menjadi anggota komunitas belajar (learning community) dan lebih kolaboratif. Tidak hanya perpaduan pada metode belajar, namun kedua lembaga juga mengombinasikan antara materi akademik dan juga soft skills persiapan kerja guna dapat memberikan pengalaman belajar yang lebih komprehensif dalam program tersebut.

Secara keseluruhan, penelitian ini akan mengevaluasi pencapaian hasil (outcome) secara individual pada remaja putus sekolah berdasarkan pada indikator yang telah ditetapkan oleh pelaksana dari program RGDB Paket C tahun 2018-2019. Para penerima manfaat tersebut merepresentasikan mereka yang memiliki tujuan untuk bekerja atau melanjutkan ke pendidikan tinggi setelah menyelesaikan keseluruhan program.

\section{METODE}

Pendekatan penelitian ini adalah kualitatif yang mempunyai kekuatan untuk menghasilkan penelitian yang komprehensif, sehingga menjadi lebih lengkap dalam upaya memaknai secara mendalam pada fokus penelitian (Babbie, 2010). Jenis penelitian yang digunakan adalah evaluasi sumatif, bertujuan untuk mengumpulkan dan menyajikan informasi yang dibutuhkan untuk rangkuman dan penilaian mengenai program dan nilainya (Herman et al., 1987). Studi outcomes pada evaluasi sumatif menguji hal-hal yang tercapai atau tidak tercapai pada masing-masing individu remaja putus sekolah yang kini telah kembali ke masyarakat setelah menuntaskan program RGDB 
Paket C. Dengan begitu, klarifikasi dan pengukuran program dapat membantu perancang dan staf pelaksana selanjutnya untuk dapat lebih fokus pada activities yang harus dijalankan dan membuat perbaikan pada bagian yang gagal dicapai. Melakukan evaluasi outcomes secara sistematik berguna untuk membuat penilaian mengenai program, meningkatkan efektivitas program, dan/atau menginformasikan keputusan tentang program yang akan datang (Patton, 2015). Ruang lingkup evaluasi outcomes berfokus pada kepuasan program, pengetahuan atau kemampuan yang diperoleh klien, serta outcome lain yang tak terduga dan terasosiasi dengan program. Kesuksesan atas program sosial dan pendidikan ini berasal dari kebutuhan dan keadaan individu yang mengalaminya. Evaluasi berbasis individu akan menghasilkan variasi outcome yang berbeda-beda.

Dalam penelitian evaluasi, diperlukan logika model mengenai program sosial yang menunjukkan adanya hubungan antara tujuan dan intervensi program. Dengan begitu, dapat memahami bagaimana program dikonseptualisasikan. Sebuah model dapat membuat beberapa komponen program dan hubungannya dengan yang lain menjadi lebih spesifik (World Bank, 2004). Pada dasarnya, elemen-elemen yang tercakup dalam sebuah logika model evaluasi adalah: 1) input yaitu sumber daya yang berada pada program;2) activities adalah hal-hal yang dilakukan di program; 3) output berupa jumlah barang atau jasa yang dihasilkan; 4) outcomes adalah hasil langsung dari aktivitas; dan 5) impact yakni konsekuensi secara jangka panjang dari adanya suatu program. Berikut logika evaluasi pada program blended learning RGDB Paket C Tahun 2018-2019 di PKBM INTAN.

Tabel 1. Logika Model Evaluasi Program Ruangguru Digital Bootcamp Paket C

\begin{tabular}{|l|l|l|l|l|}
\hline Inputs & Activities & Outputs & Outcomes & Impact \\
\hline a. Sumber Daya & a. Pembuatan & a. 45 penerima & a. Memiliki rasa & Individu \\
Manusia & materi & manfaat & percaya diri & mandiri \\
(SDM) & b. Orientasi & menyelesaikan & b. Meningkatnya & berdaya \\
b. Fasilitas & c. Intervensi & program & kapasitas & Mampu mengurangi \\
Program & akademik & b. $85 \%$ dari & akademik & angka pengangguran \\
c. Dokumen & d. Pengembangan & penerima & atau soft & muda \\
pelaksanaan & kecakapan diri & manfaat & skills & \\
dan hasil & (soft skills) & lulus dengan & & \\
asesmen & e. Konseling & status aktif & & \\
d. Penerima & f. Reorientasi & & & \\
manfaat & & & & \\
\end{tabular}

Sumber: olahan peneliti (2021) 
Merujuk pada logika model, maka evaluasi mengacu pada pencapaian hasil atas dua poin berikut yaitu: 1) Memiliki rasa percaya diri; dan 2) Meningkatnya kapasitas akademik atau soft skills pada remaja putus sekolah. Adapun aspek outcomes ini memiliki indikator sebagai berikut:

Tabel 2. Indikator pada Aspek Outcomes Program

\begin{tabular}{|c|c|c|}
\hline Aspek & Target Pencapaian & Indikator \\
\hline \multirow[t]{2}{*}{ OUTCOMES } & Memiliki rasa percaya diri & $\begin{array}{l}\text { 1) Mau dan mampu berbicara di depan umum; } \\
\text { 2) Berani bersaing dalam mendaftar ke perguruan } \\
\text { tinggi; atau } \\
\text { 3) Melamar pekerjaan }\end{array}$ \\
\hline & $\begin{array}{l}\text { Meningkatnya kapasitas akademik } \\
\text { atau soft skills }\end{array}$ & $\begin{array}{l}\text { 1) Lulus Ujian Nasional Berbasis Komputer } \\
\text { (UNBK); atau } \\
\text { 3) Menguasai salah satu skill baru. }\end{array}$ \\
\hline
\end{tabular}

Sumber: olahan peneliti (2021)

Penelitian dilakukan dari bulan Mei hingga Agustus 2021 dengan mengambil lokasi di PKBM INTAN, Kecamatan Cinambo, Kota Bandung. Alasan pemilihan lokasi ini selain karena berdasarkan rekomendasi dari Yayasan Ruangguru, juga disebabkan pada terbukanya kesempatan untuk memperoleh akses data dan informasi yang lebih mendalam terhadap pihak lembaga. Adapun informan berjumlah 13 orang yang terdiri dari Yayasan Ruangguru, PKBM INTAN, pendamping, dan penerima manfaat dalam rentang usia 18-21 tahun dengan latar belakang putus sekolah yang berbeda. Pemilihan informan menggunakan teknik sampel nonprobabilitas dan metode snowball (disebut juga network, chain referral) yaitu informan dipilih dimulai dengan satu atau beberapa orang dan meluas atas dasar saling terkait pada suatu kasus. Keistimewaannya adalah bahwa setiap orang atau unit terhubung dengan orang lain, melalui hubungan langsung atau tidak langsung.

Dalam upaya menjawab pertanyaan penelitian, pengumpulan data dilakukan melalui berbagai sumber untuk menjadi temuan-temuan dalam sebuah fenomena sosial yang dapat diverifikasi (Bryman, 2012). Pengumpulan data primer melalui wawancara mendalam terhadap informan yang menggunakan wawancara semi-terstruktur, yakni antara wawancara terstruktur dan mendalam yang mengikuti garis besar topik dengan beberapa pertanyaan dan petunjuk yang telah diuji sebelumnya di setiap bagian (Alston \& Bowles, 2003). Wawancara semi-terstruktur dapat menjadi instrumen untuk peneliti mencari tahu tentang suatu topik dan/atau sedikit pengetahuan mengenai apa yang dipikirkan responden. Sementara pengumpulan data sekunder melalui studi literatur dan dokumentasi. Studi 
literatur menyampaikan bahwa terdapat usaha untuk memperoleh penelitian yang serupa dan sesuai dengan topik yang diangkat oleh peneliti dalam bidang kesejahteraan sosial. Dalam hal ini dokumendokumen kualitatif terkait program Ruangguru Digital Bootcamp Paket C, serta dokumen-dokumen yang bersifat privat seperti rencana dan laporan pelaksanaan program yang telah disusun oleh pihak Yayasan Ruangguru merupakan bentuk dari studi dokumentasi.

Penelitian ini menggunakan model Guba untuk menilai data kualitatif agar menjadi dapat dipercaya (Krefting, 1991). Model didasarkan pada identifikasi empat aspek kepercayaan (trustworthiness) yang relevan dengan studi kualitatif, yakni nilai kebenaran (truth value), penerapan (applicability), konsistensi (consistency), dan netralitas (neutrality).

\section{HASIL DAN PEMBAHASAN}

Penelitian ini melibatkan 13 informan yang terdiri dari 3 informan utama dan 10 informan pendukung. Informan utama merupakan penerima manfaat program RGDB Paket C yang telah selesai mengikuti program selama tahun 2018-2019, sedangkan informan pendukung adalah para pihak yang terlibat dalam program dan mengetahui para informan utama sebelum dan sesudah keberlangsungan program.

\section{Peningkatan Rasa Percaya Diri dan Kapasitas Akademik pada Penerima Manfaat dengan Tujuan Melanjutkan Pendidikan Tinggi}

Informan remaja putus sekolah pertama adalah SA (21 tahun saat ini dan mengikuti program di usia 18 tahun) asal Melawi, Kalimantan Barat. Informan merupakan siswa putus sekolah sejak kelas 10 karena alasan berpindah tempat tinggal dari Kota Banjarmasin ke Kabupaten Melawi dan ketidakmampuan orang tua untuk membiayai pindah sekolah. Selama dua tahun putus sekolah, aktivitas harian informan hanya di rumah dan membantu orang tua mengurus kebutuhan rumah tangga. Sejak awal putus sekolah, keluarga informan berkomitmen dengan mulai mengumpulkan uang untuk kembali mendaftarkannya di tingkat SMA. Begitu pula informan juga memiliki keinginan untuk meneruskan ke kelas 11 dan bercita-cita lulus sekolah, agar dapat memperoleh kesempatan untuk dapat mendaftar ke perguruan tinggi.

"Keluargaku dari dulu suka pindah-pindah karena kan ngikutin kerjaan Bapak. Sedih tapi pasrah aja sekolahnya jadi keputus gitu, mau daftar di sekolah baru biasanya ada uang pangkal lagi, nggak cukup pake bayar SPP aja. Karena uangnya belum ada. Yaudah jadi di rumah aja, bantu-bantu Ibu, sama baca-baca buku yang dulu dipake di sekolah. Tapi kan tetep aja kalo belajar dari baca-baca gitu, nggak bisa dapet ijazah. Jadi, Bapak sama kakak yang udah kerja, 
janji sambil nabung buat aku bisa daftar sekolah lagi di Melawi sini. Soalnya pingin banget bisa ngerasain kelas 11 dan kuliah nantinya.” (Siswa, SA, 8/05/2021)

Kemudian, informan memperoleh informasi dari salah satu teman yang juga mengalami putus sekolah, bahwa terdapat program RGDB khusus siswa yang ingin mengejar Paket C. Kegiatan pembelajaran sebenarnya belum mencakup ke wilayah Melawi. Meski demikian, informan mencoba mendaftar dan bertanya-tanya kepada penyelenggara terkait program. Selain lokasi, pada dasarnya profil informan dari segi usia dan persyaratan lain sebagaimana kriteria siswa putus sekolah yang dapat mengikuti program sudah sesuai. Maka, pihak Yayasan Ruangguru dan PKBM INTAN berusaha mengakomodasi kebutuhan dengan memperbolehkan mengikuti kelas jarak jauh (online learning) dalam beberapa bulan pertama. Serta, informan dapat mengejar ketertinggalan pembelajaran tatap muka dengan datang langsung ke PKBM INTAN di Bandung pada beberapa bulan setelahnya. Mengenai hal ini, ketua PKBM INTAN menyampaikan:

"Setelah di-assess profil anaknya, memang keliatan yang butuh bimbingan dan mau belajar sungguh-sungguh, jadi kita terima. Kalaupun lokasinya jauh, kan mayoritas belajarnya di program ini memang online pakai aplikasi ya. Nah buat kita ngakalin ngasih materi yang dilakukan tatap muka, jadinya tiap ada pelajaran akademik atau soft skills kita kirim materinya ke dia. Bahkan dia ikutan belajar di kelas lewat platform namanya Edmodo gitu. Dulu tahun 2018 belum kenal Zoom. Gitulah jadinya kurang lebih selama 2-3 bulan begitu, sampai dia bisa datang ke Bandung. Dari kitanya, cara begitu nggak jadi penghambat belajar kok. Padahal dulu belum jamannya sekolah daring, tapi bisa-bisa aja.” (Ketua PKBM INTAN, LA, 19/08/2021)

Saat awal mengikuti kegiatan, informan adalah remaja yang pendiam, merasa malu, dan mudah gugup ketika berhadapan dengan orang lain. Beberapa tahun mengalami ketertinggalan pelajaran juga membuatnya tidak cukup percaya diri untuk berinteraksi pada guru atau sesama teman di kelas, sekalipun melalui daring. Menjalani keseharian hanya di rumah juga menjadikannya tidak terbiasa dengan aktivitas seperti berdiskusi maupun menyampaikan pendapat. Apalagi ketika memutuskan untuk merantau ke kota besar di Bandung, lingkungan yang sangat berbeda dengan di daerah asalnya menghadirkan rasa takut pada informan untuk dapat berhadapan dengan orang-orang yang sebelumnya tidak pernah dijumpai.

“Aku kan lama di pedalaman Kalimantan ya di Melawi, ketika ada kesempatan belajar bareng sama anak-anak di Bandung dan bahkan mmm dateng ke sana buat belajar di PKBM, aku tuh gugup. Selama kelas online, aku juga diem aja. Nanyanya tetep ke orang rumah. Ngobrol sama orang baru itu malu pokoknya, minder juga kalo di kelas. Kalo di sesi tatap muka terus mesti maju satu-satu, belum dipanggil guru ke depan aja udah keringet dingin. Wawancara 
sama orang apalagi, nggak berani, takut. Soalnya yang begitu-begitu kan memang nggak pernah dilakuin selama aku belajar di rumah." (Siswa, SA, 8/05/2021)

Kondisi tersebut tidak berlangsung lama, keikutsertaan informan dalam program RGDB Paket $\mathrm{C}$ memicunya untuk berinteraksi dengan orang-orang yang juga memiliki masalah serupa dengannya. Informan mulai merasa nyaman dengan lingkungan sekitar termasuk dengan para pendamping dan tutor pengajarnya. Informan menjadi banyak bertanya dan secara pribadi meminta tips untuk diajarkan berbagai hal baru supaya dapat lebih berani dan percaya diri.

"Kan udah agak lama kenal, aku udah sering ngobrol jadinya sama orang-orang di program ini. Kepinginlah juga bisa ngomong lancar kayak kakak pendamping sama tutor. Mereka kan kalo nerangin bisa tenang, lancar. Yaudah aku nanya gimana caranya bisa berani dan pede gitu kalo mereka lagi di depan banyak orang. Terus dikasih tau sama kakak-kakak Ruangguru tipsnya. Misalnya aku harus tenang, ambil napas atau minum sebelum maju ke depan, yakin kalo omongan aku didengerin lawan bicara, kalo bicara mesti lantang, artikulasi jelas, gitu-gitu intinya. Sama yang paling penting sebenernya aku diajak latihan sama pendampingku terus sih, di luar jadwal sesi kelas ya. Jadinya, makin lumayanlah. Malu sih kadang ada ya, tapi di awal doang bentar aja, kalo udah ngomong jadi lupa sendiri sih. Terus hmm aku makin biasa juga bisa ngobrol panjang sama orang yang baru kenal.” (Siswa, SA, $8 / 05 / 2021)$

Merespon hal ini, Project Officer program dari Yayasan Ruangguru menyampaikan bahwa materi pembelajaran yang relevan telah menunjang siswa dalam meningkatkan kemampuan yakni salah satunya di bidang public speaking.

"Siswa kami itu bilang, topik-topik di kelas soft skills memang bikin kepercayaan diri dia jadi membaik banget. Dari yang awalnya suka minder di antara siswa yang lain, ngerasa malu nggak bisa apa-apa. Tapi karena mau belajar, rajin nanya, ya public speakingnya pun malah jadi bagus. Bahkan dia nanya yang lebih detail dari yang disampaikan di kelas, minta dilatih juga, bahkan pake bahasa Inggris karena mau kuliah jurusan itu.” (Project Officer Yayasan Ruangguru, LN, 2/05/2021)

Selain memunculkan rasa percaya diri, informan SA juga berhasil lulus ujian di bidang akademik yang membantunya dapat bersaing untuk mendaftar ke perguruan tinggi sesuai dengan peminatan yang diinginkan. Materi di tiap mata pelajaran dianggap sesuai dengan kebutuhannya dan cara penyampaian dari tutor juga dapat dipahami sehingga membuat informan tidak pernah absen dalam pembelajaran. Di luar pembahasan materi tersebut, informan juga memperoleh kumpulan soal 
latihan, kisi-kisi cara menjawab ujian, dan juga pembekalan khusus persiapan kuliah yang hanya diberikan kepada penerima manfaat dengan tujuan masuk perguruan tinggi.

"Aku bersyukur banget bisa kebantu belajar, materi yang dikasih bagus-bagus, penjelasannya tuh rinci, mudah dimengerti, terus dikasih latihan-latihan kuis, sampe kisi-kisi jawab ujian eee apa ya jadi sangat memudahkan akulah karena metode belajarnya tuh macemmacem. Aku jadi banyak tau cara-cara jawab soal khususnya Matematika, Bahasa Inggris, sama Bahasa Indonesia. Terus udah lulus ujian sekolah, aku lanjut dikasih persiapan masuk kuliah lagi sama Ruangguru selama beberapa bulan. Latihan soal terus sampe sering jadi masuk 10 besar, ini bukan di antara teman-teman di PKBM doang, tapi se-nasional. Karena kan ada tryout online yang barengan sama siswa Ruangguru di kota lain juga. Udah beres itu, dapet sertifikat, ijazah, dan sebagainya ya jadi berani buat seriusin daftar kuliah. Karena pede gitu nilaiku bagus. Aku balik ke Kalimantan, daftar kuliah pendidikan Bahasa Inggris di STKIP PGRI dan diterima." (Siswa, SA, 8/05/2021)

Rasa percaya diri yang muncul pada informan SA untuk akhirnya mampu berbicara di depan umum dengan baik, maupun mendaftar ke perguruan tinggi berdasarkan program studi yang diinginkan, telah sesuai dengan tujuan pemberdayaan untuk memunculkan keberanian dan perubahan pola pikir. Bahwa program pemberdayaan yang telah dilakukan membantu klien agar dapat melihat dirinya sendiri sebagai solusi bagi masalah yang sedang dihadapi (Payne, 1997). Dengan begitu, selanjutnya remaja putus sekolah dapat selalu percaya bahwa akan merasa mampu meyakini diri dan dapat menjadi jawaban ketika mengalami suatu hambatan di kemudian hari.

Dalam kondisi tersebut, Yayasan Ruangguru dan PKBM INTAN juga telah berupaya menjawab tantangan untuk membangun citra diri, nilai personal (personal value) pada informan. Sebagaimana bahwa citra diri dan nilai personal merupakan bagian dari pengembangan identitas sebagai tugas utama remaja untuk dapat mengarahkan perilakunya (Chinman \& Linney, 1998). Poin ini menjadi penting sebagai langkah awal memberdayakan remaja, khususnya disaat remaja mencoba bereksperimen untuk menyeimbangkan antara kemampuan sendiri dan tuntutan lingkungan sekitarnya.

Setelah informan memiliki rasa percaya diri, pembelajaran yang diberikan selama program juga membuat remaja dapat mengenali diri dengan baik, dan mampu lebih terarah. Pembelajaran pun berjalan dengan menjadi tidak terpaksa dan dapat dilakukan dengan maksimal, serta menjadi lebih memahami alur untuk menentukan langkah selanjutnya di masa depan setelah menyelesaikan program, yakni memilih menempuh pendidikan tinggi. Dengan diperolehnya kesempatan untuk bisa 
menentukan pilihan sesuai keinginan diri, maka hal tersebut dapat lebih mudah untuk membantu mengembalikan peranan sosialnya di masyarakat (Kurniasari et al., 2009).

\section{Peningkatan Rasa Percaya Diri dan Kapasitas Akademik Serta Soft Skills pada Penerima Manfaat dengan Tujuan Bekerja}

Informan remaja putus sekolah kedua yaitu LG (24 tahun saat ini dan mengikuti program di usia 21 tahun) asal Cinambo, Jawa Barat. Informan mengalami putus sekolah karena tidak memiliki tabungan untuk melanjutkan pendidikan dan memutuskan untuk bekerja terlebih dahulu sebagai pramuniaga di salah satu pusat perbelanjaan yang berlokasi di Kota Bandung. Namun, pada faktanya dana pendidikan baru dapat terkumpul di saat sudah memasuki usia akhir pendaftaran SMA. Dengan tujuan agar lebih efisien secara waktu, maka informan memutuskan untuk memilih menyelesaikan sekolah melalui program Paket $\mathrm{C}$ dan mendaftarkan diri sebagai siswa reguler di PKBM INTAN. Namun, melihat kesesuaian profil, latar belakang ekonomi, dan tujuan informan dalam melanjutkan pendidikan yakni untuk mengejar persiapan ujian sekaligus ingin menguasai keterampilan baru di luar akademik, maka informan mendapat penawaran mengikuti seleksi program agar dapat menyelesaikan pendidikan tanpa biaya.

"Saya waktu itu kelamaan banget jeda antara lulus SMP dan masuk SMA-nya. Karena di tengah-tengah itu justru fokus kerja buat bantu ekonomi keluarga sama sekalian nabung buat lanjut sekolah. Eh, baru kekumpul uangnya pas umur udah 21, waduh kayaknya udah nggak pas lagi di umur segitu mau jadi murid SMA kan. Udah deh, ikut ujian Paket C aja. Tapi karena udah lama banget nggak belajar, jadi mau gabung di kelompok belajar gitu jadi daftar lah ke PKBM. Terus ditanya kenapa saya mau lanjut pendidikan kan, sebenernya realistis aja sih karena udah kerja jadi pengen lah punya ijazah sama mau punya skill lain juga, biar dipertimbangin buat promosi sama atasan. Terus saya dikasih tau sama PKBM kalo ada program ini, diinfonya program blended learning, jadi nggak harus tiap hari belajar tatap muka. Sayang banget lah kalo ada akses belajar fleksibel kayak gini saya lewatkan, karena cocok sama saya yang memang sambil kerja. Langsung waktu itu saya isi formnya, cuma emang katanya akan diseleksi lagi karena kan ini programnya gratis, jadi biar yang terima juga sesuai sama yang dicari penyelenggara lah. Bersyukur banget saya jadi salah satunya.” (Siswa, LG, 22/05/2021)

Sesudah menyelesaikan program, informan mengaku bahwa minat belajar yang sudah lama tidak diasah, mulai kembali muncul. Bahkan, telah menjadikan membaca buku untuk menambah ilmu sebagai salah satu hobi. Padahal sebelumnya, informan merasa enggan untuk melakukannya. Dengan mengikuti program, latihan soal-soal juga membantu dan memudahkan informan dalam memahami 
materi pelajaran yang sudah lama tertinggal. Kondisi ini yang membuatnya termotivasi untuk dapat memperoleh nilai terbaik. Terbukti, informan menduduki peringkat pertama dalam UNBK dari seluruh siswa PKBM di Indonesia yang mengikuti kelas Ilmu Pengetahuan Sosial (IPS) di program RGDB Paket C.

"Dulu rasanya baca itu asing, belajar juga jarang. Terus pas ikut program ini, kira-kira sekitar $70 \%$ itu materi yang baru lho buat saya, tapi karena dikasih banyak perumpamaan yang mudah dipahamin dari video-video belajar, jadi ngebantu buat ngerti banyak pelajaran baru. Banyak dikasih contoh soal juga kan, kalo bingung ya didampingin sama pihak PKBM. Apalagi karena belajarnya blended, bisa tatap muka dan penjelasannya makin enaklah. Di video juga bisa diulang-ulang kan sampe bener-bener ngerti. Kerasa lah belajar bisa jadi makin nyenengin, bikin tekun. Tiap beberapa hari sekali juga ada kesempatan buat saya sharing lewat WhatsApp tentang mata pelajaran yang udah dipelajari, hmm biar punya pemahaman yang sama dengan tutor atau teman. Oh, kalo pemahaman saya ternyata udah sama, udah bener, rasanya senenglah ya. Makin kemotivasi gitu kan, yes udah ngerti. Nah, ya gitu aja terus, sampe akhrinya ikut ujian dan hasilnya lho saya dikasih tau pihak Yayasan Ruangguru sama PKBM kalo ternyata bisa ranking pertama dari seluruh siswa di kelas IPS se-Indonesia." (Siswa, LG, 22/05/2021)

Dalam hal ini, pihak PKBM INTAN mengonfirmasi yang telah disampaikan oleh siswanya. Bahwa informan yang bersangkutan telah secara intens meminta pendampingan materi bahkan di luar jadwal yang sudah ditentukan. Dengan mengalami hambatan berupa jadwal belajar yang kerap terbentur dengan jadwal bekerja sebagai pramuniaga, sehingga terdapat beberapa kali pertemuan kelas yang harus terlewatkan oleh informan dan perlu dikejar dengan pembelajaran mandiri (self learning) atau pendampingan tambahan di luar waktu yang telah disepakati. Pada dasarnya pihak PKBM tidak berkeberatan untuk mendukung siswanya yang membutuhkan, apalagi informan memang memiliki tekad yang kuat untuk memperoleh promosi di kantor agar mendapatkan posisi yang lebih baik.

"Kita kan memang selalu mantau siswa didik secara berkala, kita juga taulah siapa-siapa yang sambil kerja dan memang waktunya kadang agak susah kalo izin kerja buat ikut kelas PKBM. Jadi ya udah konsekuensi juga untuk harus kasih pendampingan terpisah sesuai dengan jadwal yang dia pingin buat dia persiapan UNBK, atau sekadar ikut kelas soft skills. Yang penting anaknya rajin, nggak ngeluh-ngeluh deh. Dan pihak kita kan juga seneng, apa ya bangga gitu, yang dibawa kan nama PKBM juga gitu kalo dia ranking, oh itu anak didiknya PKBM INTAN, diupload foto dan prestasinya di sosial media Ruangguru, track record juga jadi baik, dan program RGDB Paket $C$ ini juga bisa langgeng sampe ke tahun-tahun berikutnya karena siswanya sukses.” (Tutor dan Operator, AAG, 19 Agustus 2021). 
Selain pencapaian yang diperoleh di bidang akademik, informan juga dapat menggunakan hasil pencapaian belajarnya untuk melamar ke posisi yang lebih tinggi dari sebelumnya, yakni menjadi seorang supervisor toko di perusahaan yang sama.

"Jadi di kantor saya kan memang ada posisi tertentu yang harus punya kualifikasi pendidikan tertentu, udah beberapa tahun saya kerja kan susah mau naik karena SMA aja belum lulus gitu. Jadi beres dari ikut program di PKBM dan Yayasan Ruangguru ini ya ada ijazah sama sertifikat yang bisa digunain buat ngajuin naik posisi dan alhamdulillah ya diterima sama atasan. Lumayan ini ngebantu banget, ilmu barunya dapet, memperbaiki ekonomi istilahnya atau pendapatan saya juga dapet. Bahkan, secara spesifik ada lho materi-materi kayak bahasa Inggris yang pastinya kepake untuk di kerjaan posisi baru jadi supervisor toko.” (Siswa, LG, 22/05/2021)

Dampak (outcomes) yang dialami oleh informan LG sesuai dengan pengertian dari diperolehnya pemberdayaan yang merupakan meningkatkan, menekankan, mengembangkan, dan memelihara kemampuan (Kirst-Ashman \& Hull, 2010). Tantangan yang dihadapi informan dalam pembelajaran juga mampu teratasi dengan metode blended learning yang menjadi keistimewaan program, sehingga tetap bisa menempuh pendidikan dengan lebih fleksibel. Kondisi seperti ini mampu mendukung dan meningkatkan penyerapan pengetahuan. Pembelajaran campuran berpotensi untuk membuat belajar lebih jauh serta menjadi lebih bersemangat (Thorne, 2003).

Terbukti bahwa pencapaian terhadap indikator seperti remaja putus sekolah dapat lulus UNBK dengan peringkat pertama dan menguasai salah satu skill yakni bahasa Inggris, yang juga menunjukkan sebagai langkah pemulihan kondisi remaja. Pendekatan yang berkenaan dengan pendidikan, pekerjaan, pelatihan, dan mengarahkan informan sebagai penerima manfaat untuk memiliki berbagai keterampilan dasar yang sangat dibutuhkan pada bidang pekerjaan untuk membuatnya menjadi berdaya (Santrock, 2003).

Saat remaja putus sekolah yang memperoleh program telah mampu melaksanakan tugas secara baik di masyarakat dan mandiri dalam memenuhi kebutuhannya dengan bekerja dan memperoleh pendapatan yang layak, maka program dapat dikatakan berhasil. Sebaliknya, apabila telah memperoleh bantuan program belum mampu melaksanakan peran di masyarakat dan belum dapat memenuhi kebutuhan secara mandiri, berarti terdapat kesalahan pada pelaksanaan ataupun terhadap remaja itu sendiri (Tamba et al., 2015). Kondisi yang telah dipaparkan oleh informan LG di atas memperlihatkan bahwa program RGDB Paket $\mathrm{C}$ berhasil bagi tujuan awalnya yakni mendapatkan posisi baru atau promosi di perusahaan. 


\section{Peningkatan Rasa Percaya Diri dan Kapasitas Akademik Serta Soft Skills pada Penerima Manfaat dengan Tujuan Bekerja dan Menempuh Pendidikan Tinggi}

Informan remaja putus sekolah yang ketiga adalah DS (22 tahun saat ini dan mengikuti program di usia 19 tahun) asal Mandalajati, Jawa Barat. Mengalami putus sekolah karena sulit memahami beberapa mata pelajaran yang diterima di kelas. Kemudian memutuskan untuk mengambil jeda belajar dengan memilih bekerja sebagai seorang pelayan butik. Setelah satu tahun bekerja, informan memutuskan untuk menyelesaikan pendidikan melalui sistem ujian Paket $\mathrm{C}$ pada kelas informal yang dilakukan di PKBM INTAN. Tidak seperti dua informan lainnya, DS pada awalnya tidak memiliki ekspektasi untuk bisa meneruskan pendidikan ke jenjang yang lebih tinggi, apalagi memperoleh pekerjaan yang lebih baik.

"Aku sering merasa kurang nyampe buat menyerap materi di sekolah dulu. Jadi daripada nilai terus anjlok, orang tua juga kasih saran, ambil istirahat aja. Percuma paksa sekolah juga kalo nggak ada hasil kan. Nah biar nggak kosong banget, aku ambil kerjaan jaga butik. Lagian apalagi kerjaan yang bisa dilakuin sama tamatan SMP kan ya. Tapi lama-lama setelah setahun, kok rasanya pengen tamatin SMA juga, nah ya udah deh ambil program di PKBM. Aku dapet kesempatan untuk ikut program ini, karena kan pemahaman aku tuh kurang sama cara belajar mengajar yang cuma di kelas. Jadi ditawarin yang blended juga siapa tau lebih cocok. Dan ternyata iya, aku jadi lebih paham setelah gabungin dua cara belajar kayak gini. Tapi aku pas jalanin program, awalnya ya nggak mengharap banyak sih, ikut aja udah cukup nambah ilmu sama buat dapetin ijazah.” (Siswa, DS, 18 Agustus 2021)

Menanggapi pernyataan dari informan DS, maka informan WAS selaku Staf Kesiswaan dan Kurikulum PKBM INTAN pun menyampaikan sebagai berikut:

"Sebenernya kalo dari kita kan seleksi nerima siswa itu sederhana, cukup liat tahun ijazah sebelumnya, kapan lulusnya di SMP. Jadi waktu dapet ijazah paket C setara SMA, bisa dianggap sekolah 3 tahun. Selebihnya, kita serahkan ke Ruangguru buat sortir siswanya, lewat hasil jawab pertanyaan di form. Dan ternyata untuk kondisi DS ini bisa diterima karena casenya unik, bukan cuma dari sisi ekonomi aja kayak siswa. Tapi juga ada gangguan belajar di kelas, jadi pihak Ruangguru juga bisa eksperimen untuk buktiin metode belajar campuran ini cukup efektif atau nggak. Siswa ini juga beda karena dari awal nggak ada keinginan lanjut kuliah atau kerja di perusahaan tertentu gitu, motivasinya cuma pengen belajar lebih banyak aja." (Staf Kesiswaan dan Kurikulum, WAS, 8 Mei 2021).

Menurut informan, terdapat rasa ketidakpercayaan diri di awal mengikuti program, sehingga ia tidak berekspektasi apapun. Namun, ketika sudah memulai pertemuan beberapa kali, justru informan mulai 
merasakan bahwa ada kesempatan untuk bisa meningkatkan kariernya lebih baik lagi. Beberapa materi kelas soft skill seperti tips dan wawancara kerja serta motivasi yang diberikan langsung dari kalangan profesional membuatnya tertarik untuk menerapkan hal tersebut. Selain itu, informan pun mulai memikirkan guna memanfaatkan kesempatan belajar ini untuk mempersipakan diri menempuh pendidikan tinggi.

"Ya kalo dari segi perkembangan setelah beberapa kali ikut pertemuan di program, saya sempet ngerasa lho ternyata daftar kerja di perusahaan-perusahaan besar tuh gitu ya. Oh, ternyata ini ya soal-soal buat bisa diterima kerja di sana. Dan saya punya akses buat banyak bertanya sama mentor yang ada karena mereka udah pernah punya pengalaman itu semua. Kemudian baru tau juga ternyata pasti ada materi akademik juga yang akan dites, apalagi pengetahuan pelajaran saya kan bisa dibilang kurang ya, jadi bener-bener tertarik buat manfaatin kesempatan yang ada dan langsung pingin praktekkin mumpung ada yang mau bantuin. Bahkan jadi mulai terpikir buat kerja sambil kuliah aja kok kayaknya bisa nih.” (Siswa, DS, 18 Agustus 2021)

Pada dasarnya, sedari awal kurikulum program dibuat oleh Yayasan Ruangguru dan PKBM INTAN, materi mengenai persiapan kerja telah menjadi salah satu fundamental yang didesain dengan komprehensif. Mengingat kebutuhan remaja putus sekolah yang tidak hanya ingin mengasah kemampuan akademik, namun juga skill untuk bisa memperoleh pekerjaan yang lebih baik, sehingga pernyataan yang disampaikan oleh informan DS sejalan dengan ekspektasi dari pihak pelaksana program.

"Semakin dia mau maksimalin fasilitas yang dia dapet, sebenernya kan ya semakin berperanlah fungsi kita sebagai pelaksana program. Dia mau fokus siapin tes kerja kita bantu, fokus buat kuliah kita juga seneng, apalagi kalo sampe terpikirkan mau kerja sambil kuliah. Seenggaknya sampai ke tahap dia berani dulu deh buat daftar di keduanya, itu jadi modal awalnya. Itu kan berarti nunjukkin kalo dia udah mulai menguasai dan pede dengan beberapa materi yang dia pahami itu. Selanjutnya bareng kita dan pihak PKBM buat latih dan makin asah dia menuju persiapan tesnya." (Student Relations, HD, 6 Mei 2021)

Informan DS pun telah melamar pekerjaan secara administratif di salah satu bank BUMN menjelang program RGDB Paket $\mathrm{C}$ berakhir, sambil mempersiapkan diri dari segi akademik untuk mengikuti UNBK serta tes kerja secara tertulis dan wawancara.

"Di awal sempet minder, emang bisa ya lulusan Paket $\mathrm{C}$ doang bersaing sama yang lulusan dari sekolah formal. Tapi ya aku selalu disemangatin dicoba aja kan nggak ada salahnya, biar tau kayak apa sih persaingannya. Daripada mentok karierku di jaga butik aja kan, bener 
juga sih. Aku bener-bener dengerin saran dari kakak-kakak Ruangguru dan guru di PKBM. Bener-bener belajar juga dari soal-soal yang dikasih biar aku lulus tes tulis dan interview kerja di bank. Jadi pas lulus dari tiap tahapan dari bank itu, kayak ngerasa full disupport aja. Berasa bareng-bareng berjuangnya padahal yang mau kerja tuh aku, yang lulus ujian juga aku." (Siswa, DS, 18 Agustus 2021)

Setelah lulus UNBK dan lulus tahap akhir untuk diterima bekerja di bank, informan DS memutuskan menunggu mulai bekerja sehingga bisa beradaptasi terlebih dahulu dengan alur dan jam kerja, serta mencari beberapa rekomendasi perguruan tinggi yang memiliki pilihan kelas karyawan. Baik pihak PKBM INTAN maupun Yayasan Ruangguru saling membantu memberikan informasi terkait alur dan tanggal pendaftaran, persiapan berkas, pemilihan universitas, fakultas, dan jurusan yang sesuai sampai ke tahap pendaftaran di situs penerimaan mahasiswa.

"Kita sengaja nunggu prosesnya satu-satu. Waktu dia udah bisa buktiin buat lolos seleksi sampai tahap akhir di bank, baru kita mulai sama-sama mikirin strategi buat dia bisa dapet kampus yang jam kelasnya cocok dengan karyawan. Banyak sih rata-rata kampus swasta yang punya kelas malam, dan dari dia nggak ada permintaan yang harus kuliah di mana gitu. Yang penting jadwal dan jurusannya cocok. Kita dari PKBM bantu sebisanya, dari Ruangguru punya referensi yang lebih banyak lagi. Ada beberapalah yang didaftarin pada akhirnya karena kriterianya sesuai dan sama-sama ada di Bandung." (Tutor dan Operator, AAG, 19 Agustus 2021).

Dukungan untuk berpartisipasi aktif dan melakukan tindakan positif yang diperoleh informan melalui keikutsertaannya dalam program bagi remaja putus sekolah membuatnya mampu mengidentifikasi daya atau kekuatan diri sendiri. Komponen ini merupakan kunci dari proses pemberdayaan, yang juga penting bagi perkembangan kehidupan remaja yang berubah dengan cepat (Chinman \& Linney, 1998). Informan mengalami konsep diri yang mudah berubah seiring perubahan kognitif yang cepat dan tengah bereksperimen untuk menyeimbangkan keinginan dan kemampuan baik itu dari diri sendiri maupun lingkungan sekitar. Proses pemberdayaan yang hadir dengan diawali adanya krisis yang menunjukkan informan DS sebagai remaja putus sekolah yang tidak mampu mengikuti pembelajaran di kelas formal dan tidak memiliki ekspektasi apapun terhadap masa depan termasuk kariernya.

Kemudian krisis yang dilewati tersebut memunculkan tindakan yang harus diambil untuk selanjutnya dapat bertumbuh. Kegiatan pada program yang mengarahkan diri pada kompetensi membantu sisi pengembangan diri, sifat, label, dan identitas positif. Menurut Chinman \& Linney, bahwa interaksi remaja dalam masa perkembangannya dengan teman sebaya dan orang dewasa juga 
dapat mengurangi egosentris dalam diri dan membuat remaja memiliki peran serta tanggung jawab yang lebih dewasa. Secara keseluruhan, upaya yang dalam hal ini dilakukan untuk memberdayakan informan DS, sejalan dengan elemen dasar untuk memberdayakan remaja. Terdapat lima elemen kunci guna memberikan pengalaman yang memberdayakan bagi kaum muda, yakni adanya peran orang dewasa, memberikan kesempatan remaja untuk belajar, terdapat kegiatan yang memberi peluang bagi keterampilan diri, menerima pengakuan positif, dan memastikan remaja diberi waktu untuk memberikan keputusan terhadap pengalaman yang mereka alami (French, 2015).

\section{KESIMPULAN}

Berdasarkan individualized outcomes yang dialami oleh ketiga penerima manfaat sebagai informan utama setelah mengikuti seluruh rangkaian program Ruangguru Digital Bootcamp Paket C, menunjukkan adanya pencapaian indikator keberhasilan dalam segi memiliki rasa kepercayaan diri dan meningkatnya kapasitas akademik atau soft skills. Hal ini ditunjukkan melalui kemampuan berbicara di depan umum, mendaftar ke perguruan tinggi, melamar posisi pekerjaan yang lebih baik, lulus ujian nasional, dan menguasai skill seperti cakap berbahasa Inggris serta mengikuti tes tulis dan wawancara kerja.

Perpaduan kelas blended learning dari Yayasan Ruangguru dan PKBM telah menjawab tantangan para remaja putus sekolah. Meski begitu, masih terdapat peluang untuk rekomendasi untuk dapat meningkatkan outcomes dari program ini. Ke depannya, pelaksana program dapat sekaligus mengarahkan penerima manfaat untuk mendaftar ke universitas atau melamar pekerjaan di bidang yang paling dibutuhkan saat ini. Dengan tujuan nantinya dapat benar-benar menjawab impact yang bisa mengurangi angka penggangguran muda yang keberlanjutan.

\section{DAFTAR PUSTAKA}

Alston, M., \& Bowles, W. (2003). Research for Social Workers: An Introduction to Methods. Routledge.

Babbie, E. R. (2010). The Practice of Social Research (12th ed). Wadsworth Cengage.

Badan Pusat Statistik. (2020). Angka Partisipasi Murni tingkat SMA/sederajat berdasarkan 34 Provinsi di Indonesia.

Badan Pusat Statistik Provinsi Jawa Barat. (2019). Grafik Angka Partisipasi Murni SMA/MA Paket C Tahun 2019, 9 Wilayah Jawa Barat. 
Balenzano, C., Moro, G., \& Cassibba, R. (2019). Education and Social Inclusion: An Evaluation of a Dropout Prevention Intervention. Research on Social Work Practice, 29(1), 69-81.

Bryman, Alan. (2012). Social Research Strategies: Social Research Methods. In OUP Oxford (Issue 4). Oxford University Press Inc.

Catterall, J. (2011). The Societal Benefits and Costs of School Dropout Recovery. Education Research International, 2011.

Chinman, M. J., \& Linney, J. A. (1998). Toward a Model of Adolescent Empowerment: Theoretical and Empirical Evidence. Journal of Primary Prevention, 18(4), 393-413.

French, K. (2015). Youth Empowerment as Demonstrated by The Jóvenes En Acción Program. In SIT Graduate Institute.

Herman, J. L., Morris, L. L., \& Fitz-Gibbon, C. T. (1987). Evaluator's handbook (Issue 1). Sage Publications.

Ife, J. (2009). Human Rights from Below: Achieving Rights Through Community Development. Pearson Education Australia Pty Ltd.

Kementerian Bappenas dan UNICEF. (2017). Laporan Baseline SDG tentang Anak-Anak di Indonesia.

Kirst-Ashman, K. K., \& Hull, G. H. (2010). Understanding Generalist Practice (6th ed.). Brooks/Cole.

Krefting, L. (1991). Rigor in Qualitative Research: The Assessment of Trustworthiness. The American Journal of Occupational Therapy, 45(3).

Kurniasari, A., Huruswati, I., Setiawan, H. H., \& Sabarisman, M. (2009). Penelitian Pelayanan dan Rehabilitasi Sosial Anak di Panti Sosial Marsudi Putra (Evaluasi Program Penanganan Anak Nakal). P3KS Press.

Patton, M. Q. (2015). Qualitative research \& evaluation methods: integrating theory and practice (Fourth edition). SAGE Publications, Inc.

Payne, M. (1997). Modern Social Work Theory. In Chicago IL. Macmillan.

Santrock, J. W. (2003). Adolescence: Perkembangan Remaja. Erlangga.

Tamba, E. M., Krisnani, H., \& Gutama, A. S. (2015). Pelayanan Sosial bagi Remaja Putus Sekolah. Prosiding Penelitian dan Pengabdian kepada Masyarakat, 2(2). 
Thorne, K. (2003). Blended Learning: How to Integrate Online and Traditional Learning. Kogan Page Publishers.

UNESCO Institute for Statistics. (2006). International standard classification of education ISCED 1997. UNESCO-UIS.

UNICEF. (2020). Pendidikan dan Remaja. https://www.unicef.org/indonesia/id/pendidikan-danremaja

World Bank. (2004). LogFrame Handbook: A Logical Framework Approach to Project Cycle Management. In United States: The World Bank.

Zastrow, C. (2017). Introduction to Social Work and Social Welfare: Empowering People. In Brooks/Cole-Thomson Learning. Brooks/Cole. 